\title{
EXPERIMENTS ON THE ORIGIN OF KETTLE-HOLES
}

\author{
By Judith K. Maizels \\ (Department of Geography, University College London, London WGIE 6BT, England)
}

\begin{abstract}
Several theories exist on the origin of kettle-holes in pro-glacial outwash deposits. The most widely accepted origin involves the melting of buried ice. The author carried out some experiments in which ice blocks were placed on $\mathrm{cr}$ in outwash sediments in a tank in order to determine which mechanisms of ice melt would be most likely to give rise to kettle-hole features. The largest kettle-holes were produced by the melting of buried ice blocks; smaller transient depressions were formed from ice blocks melting in streams of flowing water; while, rather than depressions, ridges resembling pingos and moraines were created by ice blocks melting on a dry or saturated gravel surface.

RÉsumé. Expériences sur l'origine des marmites. Plusieurs théories existent sur l'origine des marmites dans les dépôts proglaciaires de lavage. L'origine la plus généralement admise invoque la fusion d'une glace enfouie. L'auteur a conduit plusieurs expériences dans lesquelles des blocs de glace ont été placés sur ou dans des sédiments lavés dans une enceinte, afin de déterminer quels mécanismes de fusion de la glace auraient le plus de chance de conduire à la création de marmites. Les plus grandes marmites se sont formées par fusion de blocs de glace enterrés; des dépressions passagères plus petites se sont formées à partir de la fusion de blocs de glace dans le lit d'une eau courante; tandis que, plutôt que des dépressions, des ondulations ressemblant à des pingos et des moraines se sont formées par fusion de blocs de glace sur une surface de gravier sèche ou
saturée.

Zusammenfassung. Versuche zur Entstehung von Kesselmulden. Verschiedene Theorien versuchen die Entstehung von Kesselmulden in Sanderflächen zu erklären. Am verbreitesten ist die Annahme des Abschmelzens von verschüttetem Eis. Die Autorin führte einige Versuche durch, bei denen Eisblöcke in einem Tank an oder in Schwemmsedimente gelegt wurden, um herauszufinden, welcher Schmelzmechanismus am ehesten Anlass zur Bildung von Kesselmulden gäbe. Die grössten Kesselmulden wurden beim Abschmelzen verschütteter Eisblöcke erzeugt; kleinere, vorübergehende Senken ergaben sich beim Abschmelzen von Eisblöcken in Strömen fliessenden Wassers; dagegen bildeten sich anstelle von Senken Rücken, die Pingos und Moränen glichen, wenn Eisblöcke auf einer trockenen oder wasserdurchtränkten Kiesfläche schmolzen.
\end{abstract}

\section{Definitions}

Kettle-holes are shallow depressions which frequently occur on pro-glacial outwash plains. Most kettle-holes are less than $8 \mathrm{~m}$ deep but some attain depths of over $20 \mathrm{~m}$ and are up to $2 \mathrm{~km}$ wide (Flint, I97I, p. 212-I4). They may occur as isolated pits separated by undisturbed sections of outwash (Fig. I) or as a series of interlocking depressions (Fig. 2). Kettle-holes have been reported from many present-day pro-glacial environments and have been observed in different stages of development (see Fahnestock, 1963, p. 40; Price, I97 I, p. 236; Maizels, unpublished, p. I54-66). Kettle-holes may rapidly fill with water during the melt season (see Fig. 2) and consequently sediments brought in by melt-water streams accumulate on the floor of the kettle-hole, eventually filling in the whole depression until it is obliterated. Finely laminated kettle-hole sediments and kettle-hole depressions have also been described from palaeo-outwash deposits (see for example Figure 3 ).

\section{Theories of KettLe-Hole Formation}

The principal theories which have been proposed to account for the origin of kettle-holes include the melting of ice lying on the ground surface, the melting of partially buried ice and the melting of buried ice.

\section{Melting of ice lying on the surface}

Several workers have claimed that kettle-holes may result from in situ melting of stagnant blocks of ice lying on the surface and which have become detached from the main ice mass (e.g. Ives and Andrews, I963, p. 27 and 32 ; Broscoe, 1972, p. 47). A pit-like feature is said to 


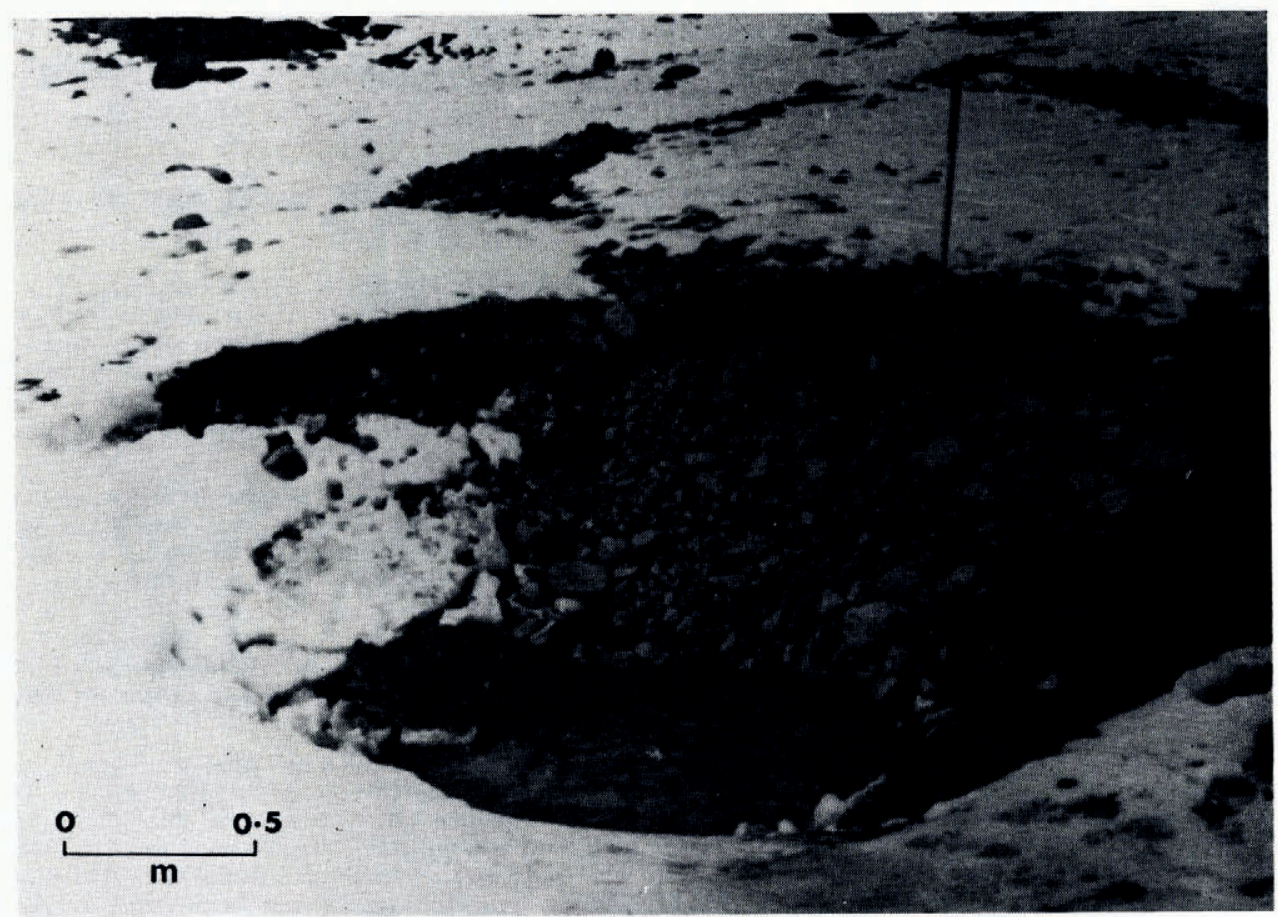

Fig. I. An isolated kettle-hole in winter on the Bossons valley train, Haute Savoie, France. The diameter of the kettle-hole is $2.8 \mathrm{~m}$ and its maximum depth is $1.4 \mathrm{~m}$. The camera is facing south-west.

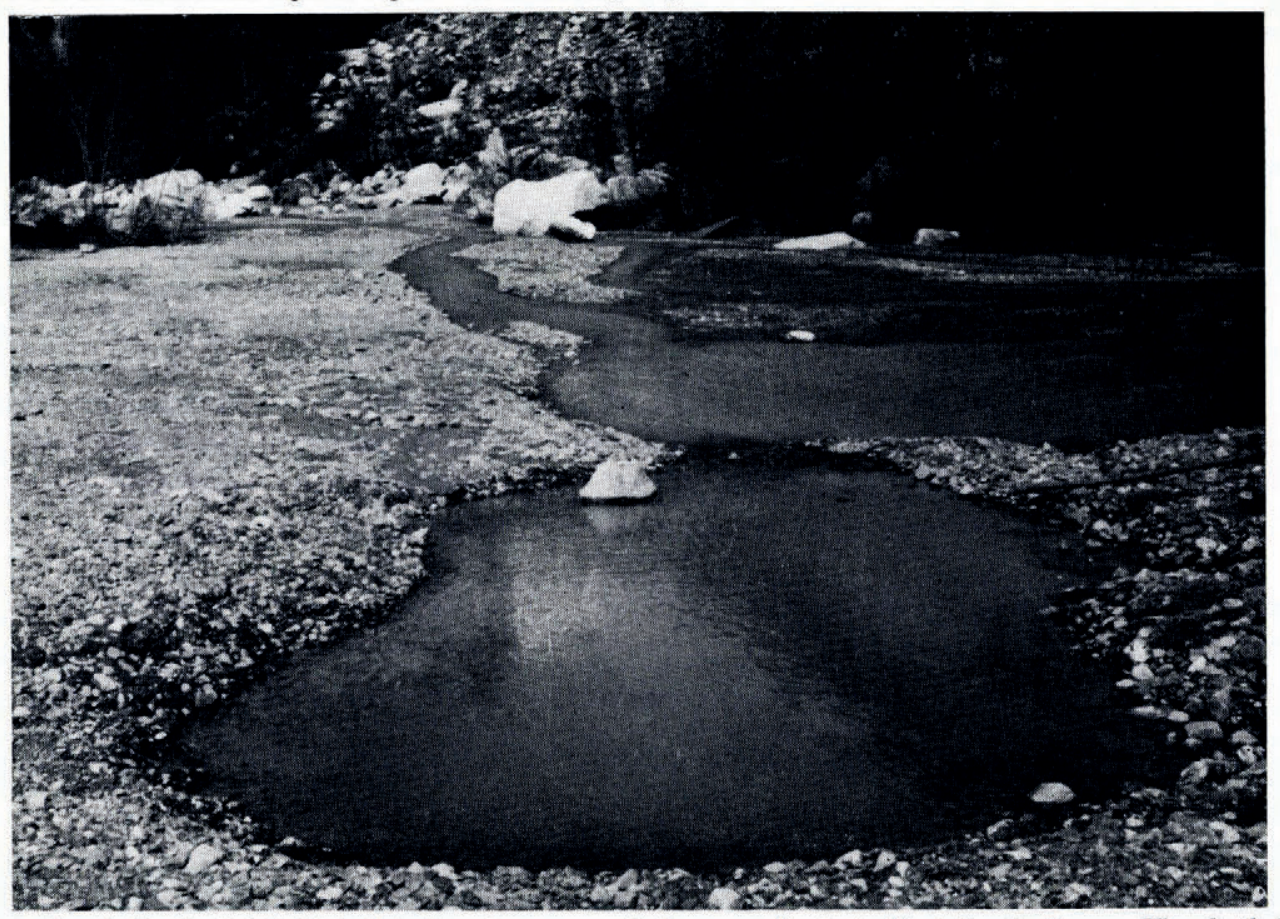

Fig. 2. Interlocking kettle-hole "lakes" in the melt season on the Bossons valley train, Haute Savoie, France. These kettle-holes are over $1.5 \mathrm{~m}$ deep and are floored by over $0.3 \mathrm{~m}$ of finely laminated silts and clays. The melt waters filled the kettle-holes within $5 \mathrm{~h}$ at the beginning of the melt season. The diameter of the kettle-hole in the foreground is $4.2 \mathrm{~m}$. 


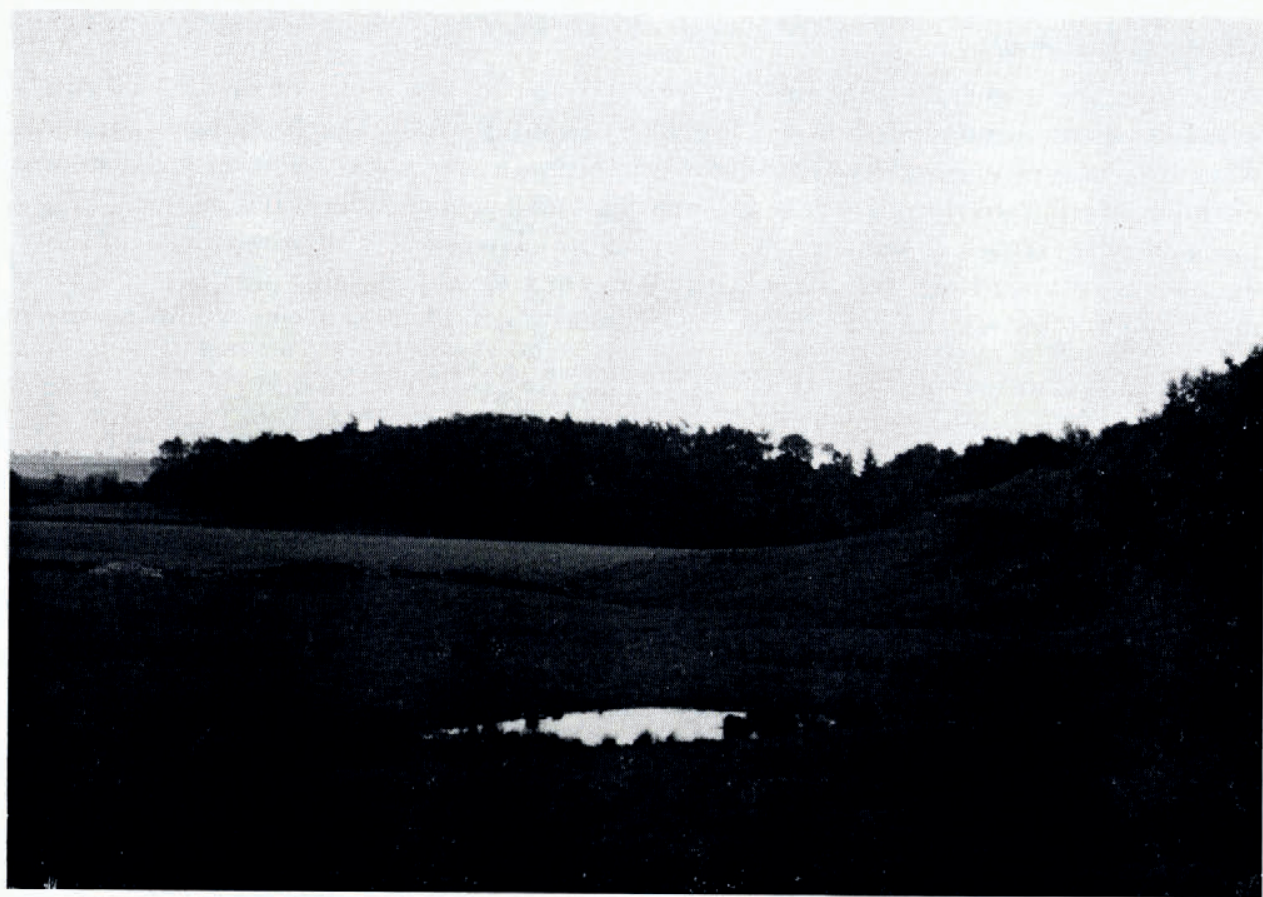

Fig. 3. Marshy kettle-hole depression in Weichselian outwash deposits, Angus, Scotland.

form by the re-settling of sediments beneath the block of ice as a result of the weight of the ice block and the sapping of surrounding sediments by melt water derived from the ice block itself.

\section{Melting of ice partially buried in melt-water streams}

Blocks of ice transported by melt waters on to the outwash plain may become partially surrounded by fluvio-glacial sediments (Hobbs, I93 I, p. 382; Fahnestock, I963, p. 8; Broscoe, I972, p. 47). The ice block melts rapidly because of insolation from above and persistent undercutting by melt waters, and sinks into the outwash deposits to form a kettle-hole (e.g. see Davis, I89o, p. I99; Thwaites, I926, p. 315; Lougee, I940, p. 199; Cotton, 1942, p. 329; Michel, r969, p. 72 I ; Klimek, r973, p. 95; Embleton and King, 1975, p. 517).

\section{Melting of buried ice}

The most widely accepted explanation of kettle-holes is associated with the melting of ice buried beneath a cover of outwash deposits which accumulated during a period of progressive ice-marginal and pro-glacial sedimentation. Geikie (1894, p. 748-49), Gilbert (1904, p. 54-55) and Fuller (1914, p. 39-42) described pits and hollows ascribed to this mechanism, and many other workers agree that kettle-holes form when ice melts out beneath a cover of till or outwash deposits (e.g. Price, I969, p. 31-33, I971, p. 236, I973, p. I63-7I; Flint, I97I, p. 212-I4; Galon, I973, p. I47; Klimek, I973, p. 95; Embleton and King, r975, p. 501-02). The buried ice may be in the form of a stagnating ice terminus (Gilbert, 1904, p. 54-55; Tarr, I 9o8, p. 94-96; Rich, I943, p. 95-96) or in the form of blocks or thin sheets of ice which have become detached from the major ice body (e.g. Thwaites, I926, p. 31 i ; Cotton, 1942, p. 329; Jewtuchowicz, I971, p. 46, 1973, p. 121; Price, I973, p. I63 and 207). 
Other modes of formation

Some other theories have been proposed to account for the origin of pro-glacial pits, such as stream scour or aeolian deflation (Thwaites, 1926, p. 309), the freezing of small lakes,

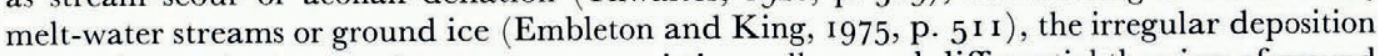
of moraine at the ice margin or across pre-existing valleys, and differential thawing of ground ice (i.e. thermokarst pits) (Flint, I971, p. 212-14). These types of pro-glacial pits are not strictly speaking kettle-holes (see Clark, 1969 ) as they do not develop directly as a result of the melting of glacier ice, i.e. ice which was originally attached to a larger moving ice mass.

\section{Simulation EXPERIMENTS}

\section{Aim of experiments}

A series of ice blocks was placed on or in sediment in a tank in order to determine the most likely ways in which kettle-holes might develop. The size and shape of the resultant depression or configuration of the sediment surface were compared to the size and shape of the original ice block. Varying degrees of slope and saturation of the sediment were used to ascertain the conditions most favourable to kettle-hole development.

\section{Experimental method}

A transparent perspex tank $30 \mathrm{~cm}$ long, $20 \mathrm{~cm}$ wide and $20 \mathrm{~cm}$ deep was filled with alternating layers of fine and very fine sediment (i.e. $0.063^{-2.000} \mathrm{~mm}$ and less than $0.063 \mathrm{~mm}$ in diameter, respectively), with fines on the surface and coarse gravel (larger than $8 \mathrm{~mm}$ in diameter) at the base. Ice blocks of different sizes and shapes were (a) placed on the surface of the sediments, (b) partly buried in the sediments in streams of flowing water and (c) buried beneath the surface of the sediments (see Table I). Experiments involving running water employed water at temperatures of between 2 and $5{ }^{\circ} \mathrm{C}$. Any changes in micro-relief of the surface were recorded together with the rates of ice melt and extent of moisture absorption by the sediment. Photographs were taken at frequent intervals during each series of experiments. The experiments are summarized in Table I, and the results are illustrated diagrammatically in Figure 4.

TABLE I. TANK CONDITIONS FOR KETTLE-HOLE EXPERIMENTS

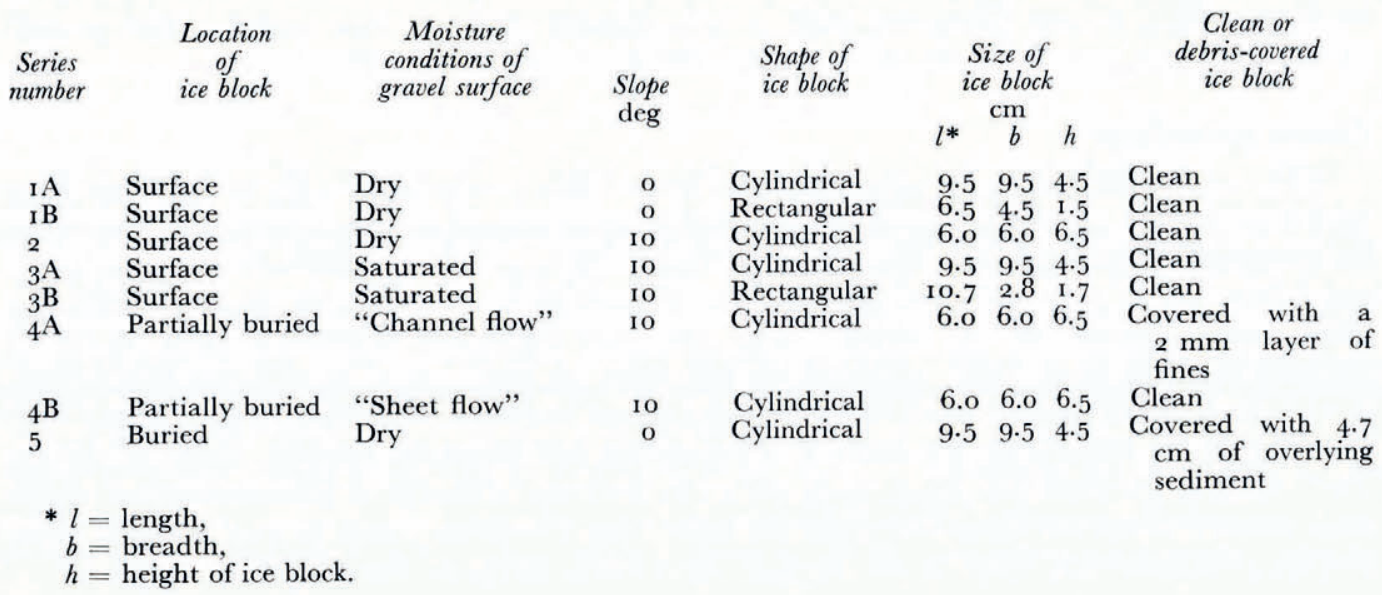




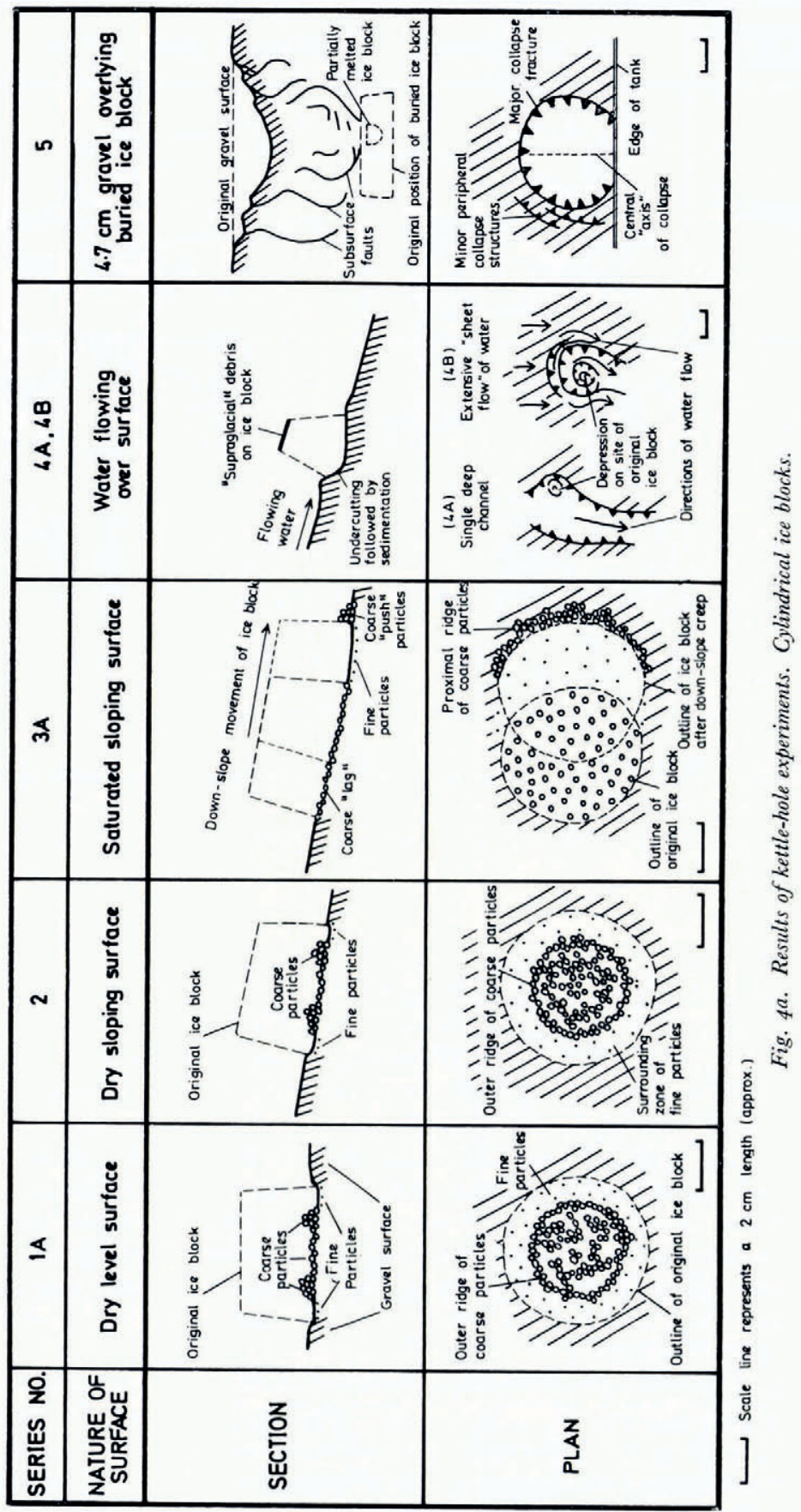




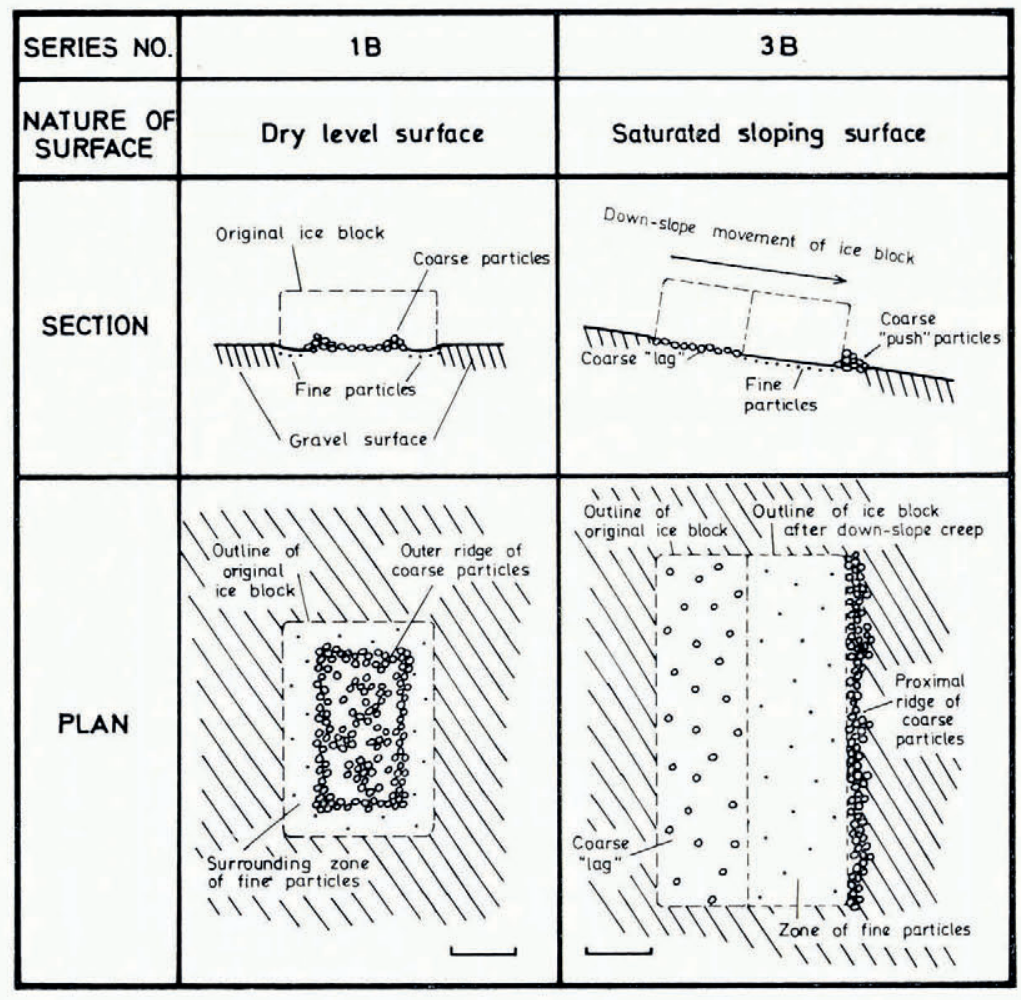

Scale line represents a $2 \mathrm{~cm}$ length (approx.)

Fig. 4b. Results of kettle-hole experiments. Rectangular ice blocks.

\section{Results of experiments}

Melting of an ice block on a dry level surface (series $I A$ and $I B$ ). Ice blocks situated on a dry level sediment surface were most effectively reduced in size by basal melting. Both the heat from the underlying sediments and the pressure exerted on the basal ice by the weight of the whole ice block acted to produce most rapid melting at the ice-gravel contact. The melting of the ice block created a thin film of melt water between the ice surface and the sediment grains; the force of surface tension effected by this intervening layer of water was sufficiently great to attract and "hold" the coarser grains against the basal ice, and even to lift these grains and stack them to a height of several millimetres up the sides of the ice block. The finer grains were more easily washed away by the dissipating melt water, while the coarse grains continued to be attracted and held against the ice as the ice block contracted. As soon as there was no further space on the ice-gravel contact zone of the ice block for any additional grains, further melting of the sediment-enriched ice surface resulted in the re-deposition of these grains on to the gravel surface.

The resultant surface form comprised a coarse-grained central mound and an encircling finer-grained zone from which the coarse grains had been removed by melt-water surface tension (see Figs 4 and $5 \mathrm{a}-\mathrm{d}$ ). The coarse-grained outer ridge was formed by the deposition of grains, which had become concentrated round the margin of the contracting ice block, as a result of being attracted both to the base of the ice block and also up the sides of the ice block (see Fig. 6). The width of the surrounding fine-grained zone depended on the basal area of the ice block, and on the size and density of coarse grains distributed on the sediment surface. 

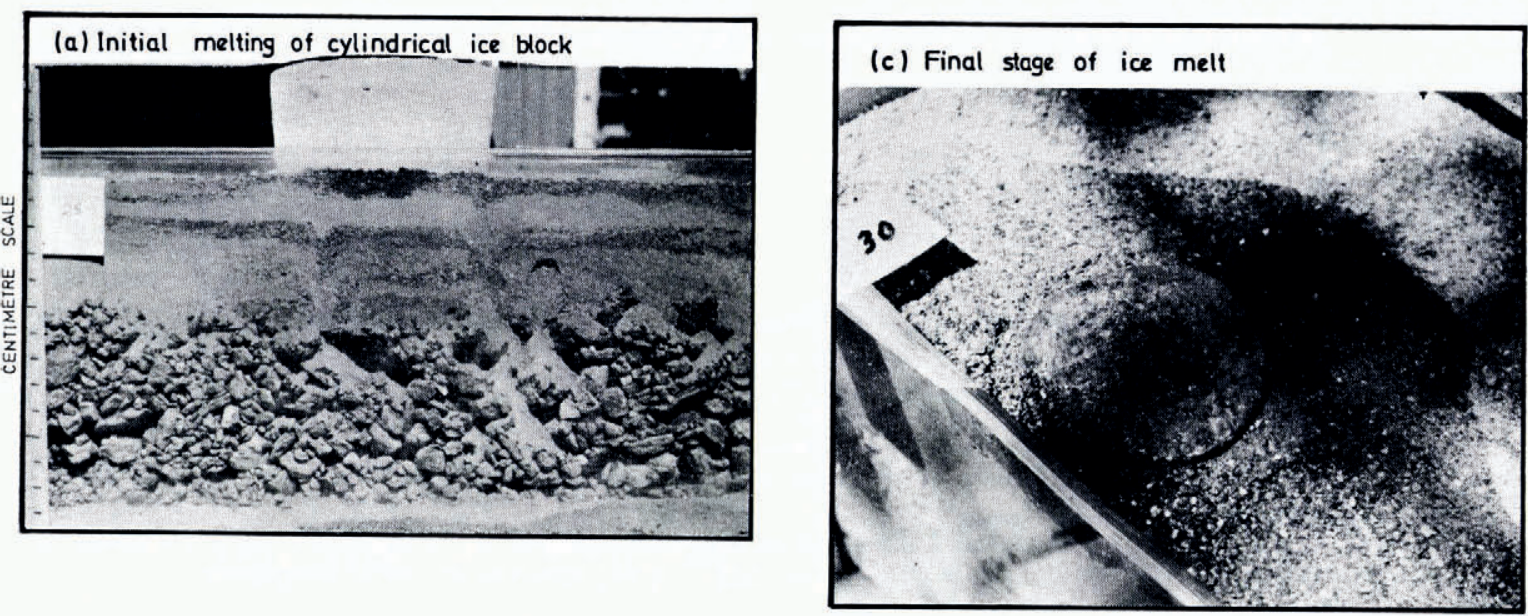

(b) Ice block one hour later:

attraction of gravel particles into base of ice block

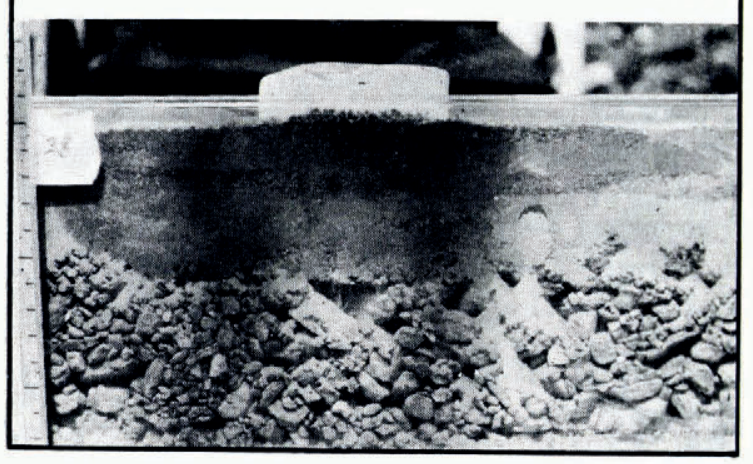

(d) Circular ridge of grains left on surface after final melting of ice block
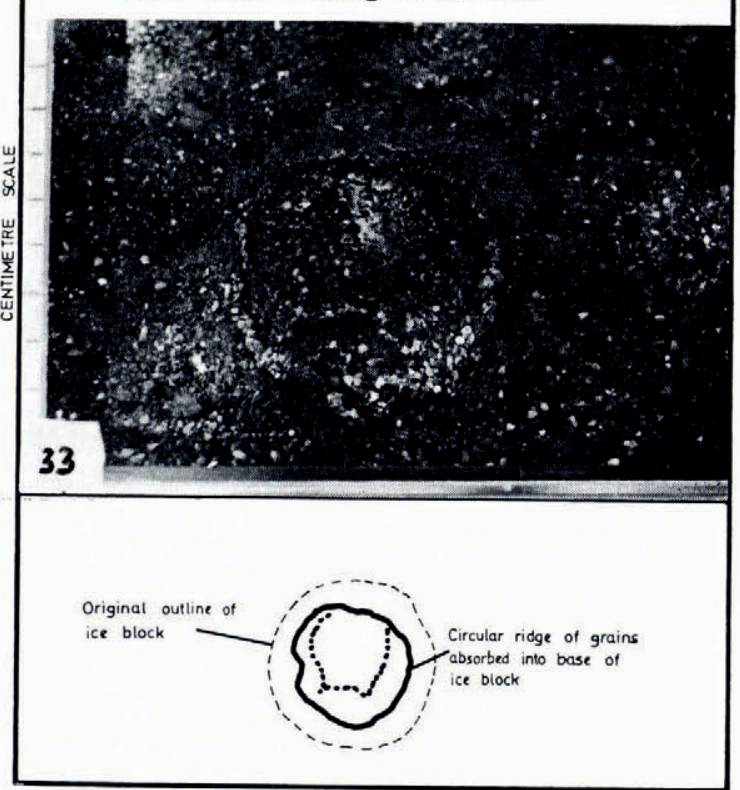

Fig. 5. Melting of an ice block on a dry level sediment surface. (a) to $(d)$ as labelled.

The surface configuration created by the melting of a cylindrical ice block bears a striking resemblance to pingo forms, as described in Finnmark by Svensson (1964) and in many other areas by Flemal (1976). Svensson suggested that the depressed centres of pingo mounds might have been created by the subsidence and melting of surface blocks of ice derived from a retreating or stagnating glacier. The encircling ridges were described as rich in coarse material, while the floors of the pingo depressions were described as fairly flat with occasional smaller ridges and channels. These features closely resemble those created experimentally and illustrated in Figures 4 a, 5 and 6 . The formation of pingo-like features on the experimental 


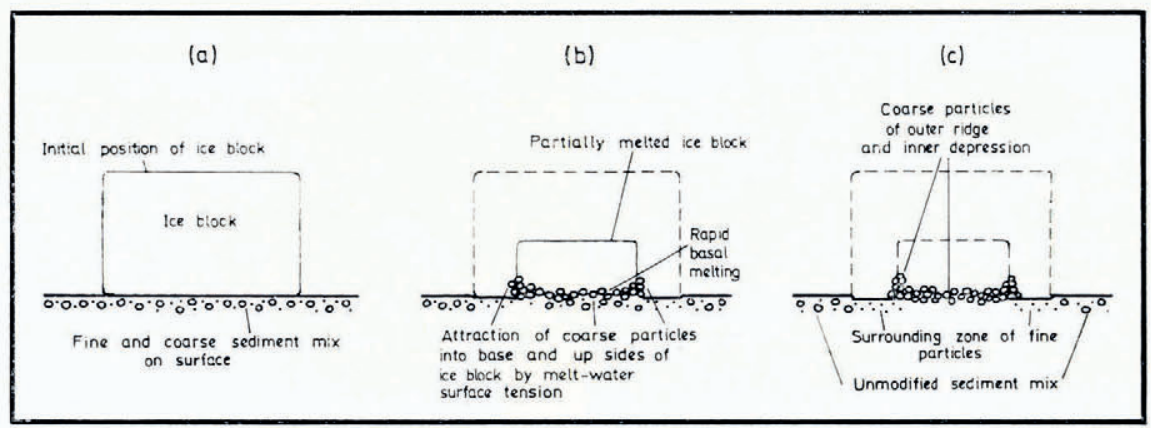

Fig. 6. The formation of a sediment ridge by the melting of a surface ice block:

(a) Ice block placed on sediment surface.

(b) Absorption of coarse particles into ice block during rapid basal melting.

(c) Outer ridge of coarse particles formed after final melting of ice block, surrounded by zone of fine sediment.

scale depends on the re-distribution of sediment grains by means of melt-water surface tension, a process which can only involve grains of $2-3 \mathrm{~mm}$ diameter (personal communication from G. Scott). Further experimental evidence would therefore be required to determine the effects on surface configuration of the melting of much larger ice blocks lying on much coarser deposits.

Melting of an ice block on a dry sloping surface (series 2). The melting of an ice block on a dry but sloping sediment surface produced the same pattern of fine- and coarse-grained zones of gravel as that produced by ice melt on a dry level surface. Gravel particles were again attracted and held by means of melt-water surface tension so that they formed a layer one grain thick across the base and several grains thick up the sides of the ice block.

Melting of an ice block on a saturated sloping surface (series $3_{3} A$ and ${ }_{3} B$ ). An ice block melting on a saturated sloping surface with a gradient of $10^{\circ}$ was observed to move down-slope. Rapid down-slope movement increased the degree of basal friction; the coarser grains could not therefore be held by melt-water surface tension, so that a coarse "lag" deposit remained to mark the position of the original ice block (Fig. 4a and b). Fines, by contrast, were washed down-slope with the moving ice block, creating a zone of finer sediments where the ice block finally melted. The proximal edge of the moving ice block removed the coarse sediment fractions which lay in its path, pushing them up into a low ridge. Both cylindrical and rectangular ice blocks produced proximal ridges, the former following a slightly curved outline (Fig. 4a) and the latter a straight outline (Fig. 4b). The ridge of sediments pushed up by the moving ice block on the experimental scale resembles a morainic ridge or a push moraine found in an actual pro-glacial environment; in a periglacial environment, some analogy may be drawn between the ridges created by surface ice melt (series 3 ) and the surface form of a stone-banked lobe.

Melting of an ice block in a zone of running water (series $4^{A}$ and $4_{B} B$ ). Basal melting of ice blocks was accelerated by the influx of a stream of water, initially cooled to between 2 and $5^{\circ} \mathrm{C}$. Undercutting of the up-stream side of the ice block by "melt waters", followed by an influx of sediment derived from the flowing water, resulted in the progressive burial of the diminishing ice block. The eventual melting of the ice block was marked by the formation of a depression (Figs 4, 7 and 8). Evidence of melt-water flow around the ice block was retained in miniature scour features eroded in the surrounding sediment.

The largest depressions were formed when (a) the flow of water and of associated sediment was smaller in volume and velocity, and when (b) the ice block was free of "supra-glacial" debris. If great quantities of water were added and if the ice block was covered with debris, 

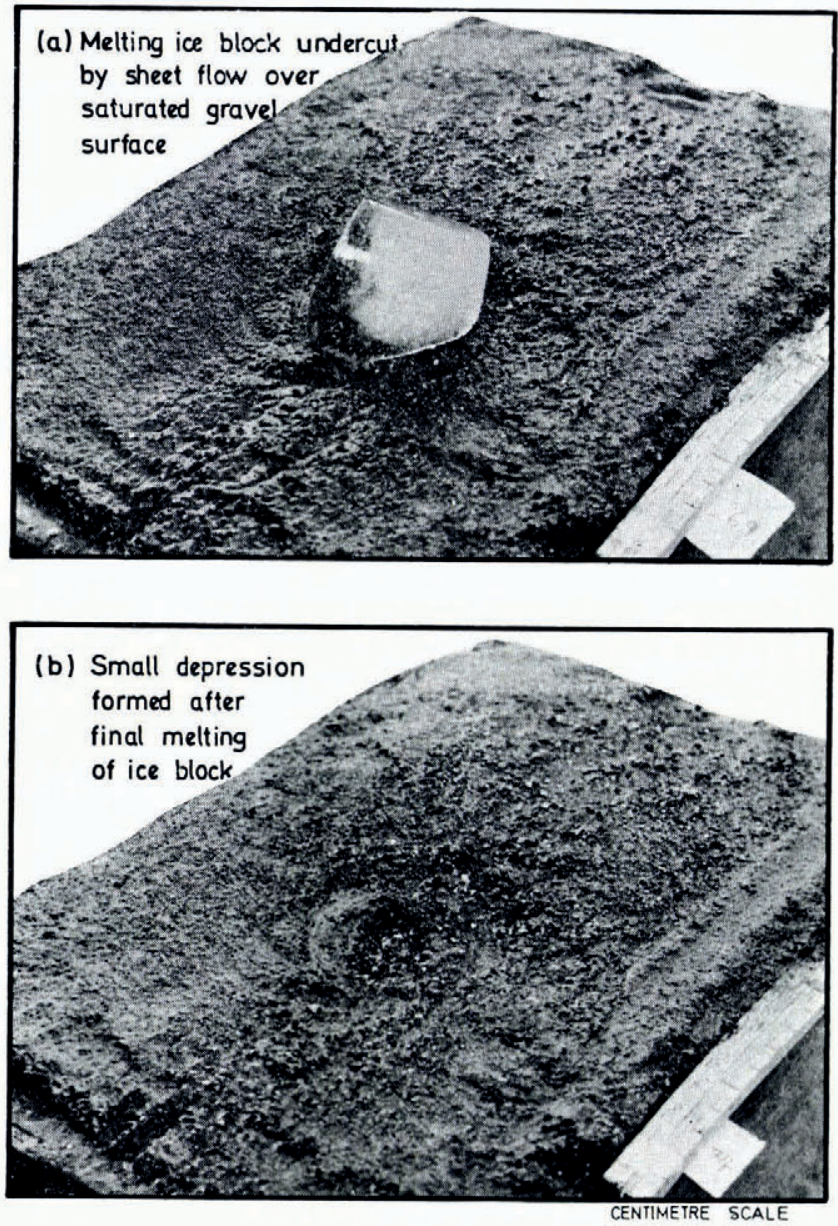

Fig. 7. Melting of an ice block on a saturated sloping surface. $(a)$ and $(b)$ as labelled.

the depression was rapidly infilled with sediment or obliterated by collapse and re-working of sediment by relatively powerful flows of water.

The combination of ice melt in a stream and associated channel scour allowed the creation of shallow kettle-holes but these were of a very temporary nature.

Melting of a buried ice block. The melting of a buried ice block produced a distinctive pit (Figs 4 and 9), accompanied by collapse structures and faults on and below the gravel surface. The depth and shape of the faults corresponded to the thickness and shape of the buried ice block. The depression was bounded by a major fracture in the sediment surface, and by minor peripheral slump features and fissures. Prominent sub-surface faults curved downwards to the top of the buried ice block. Maximum absorption of water from the melting ice block took place in the centre of the depression, so that the floor of the pit or kettle-hole was damp, while the margins and surrounding sediment surface remained dry. The sides of the depression were initially vertical or overhanging, while the floor developed a concaveupward form.

The surface depression created by the melting of buried ice most closely resembled the wide, deep and more permanent kettle-holes observed in pro-glacial outwash plains. 

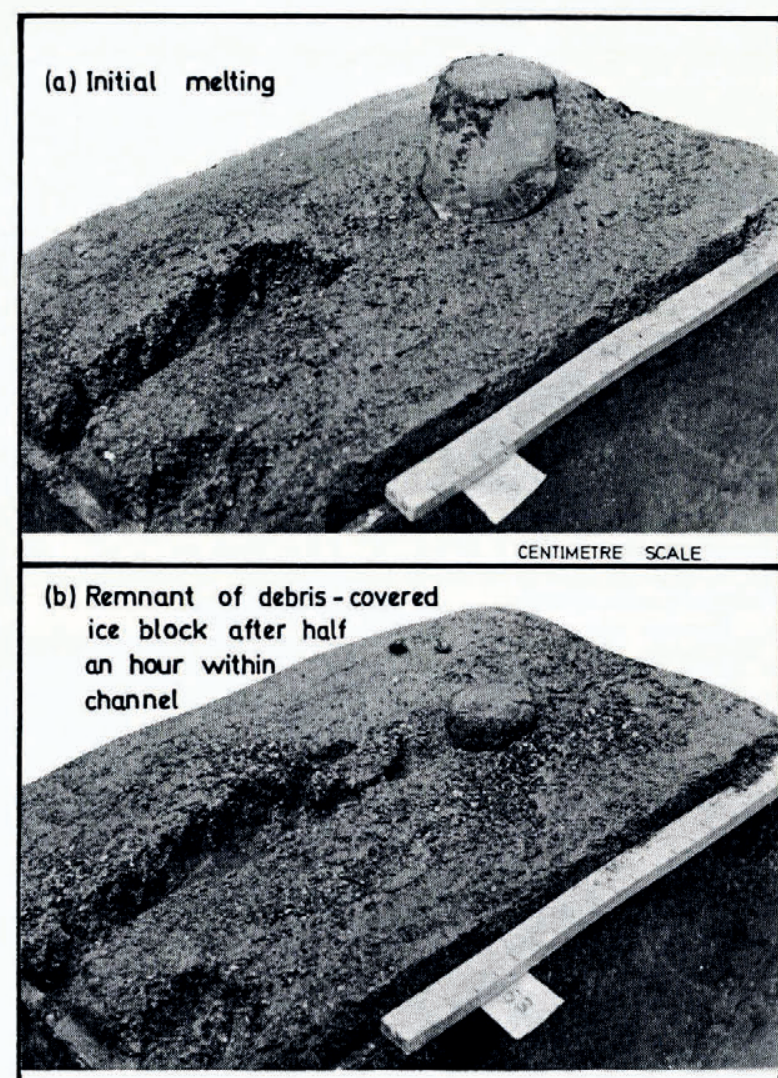

\section{(c) Small depression produced after final melting}

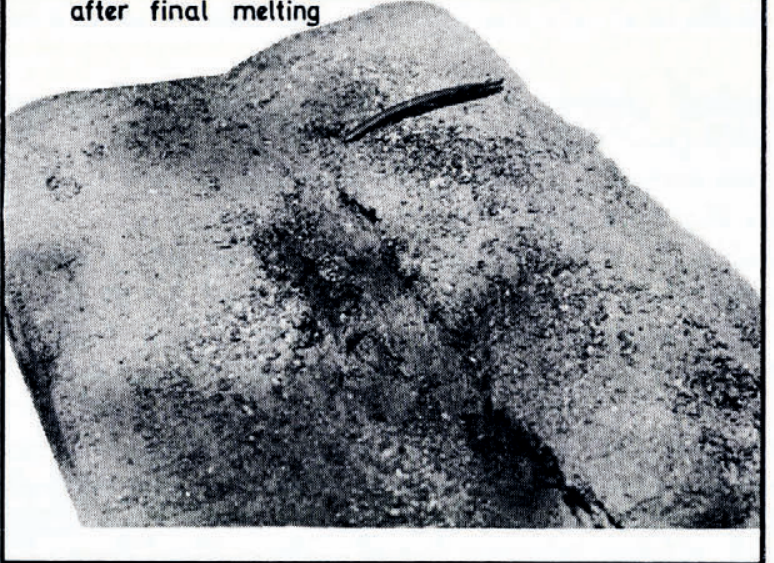

Fig. 8. Melting of a debris-covered ice block in melt-water stream channel. $(a),(b)$ and (c) as labelled. 

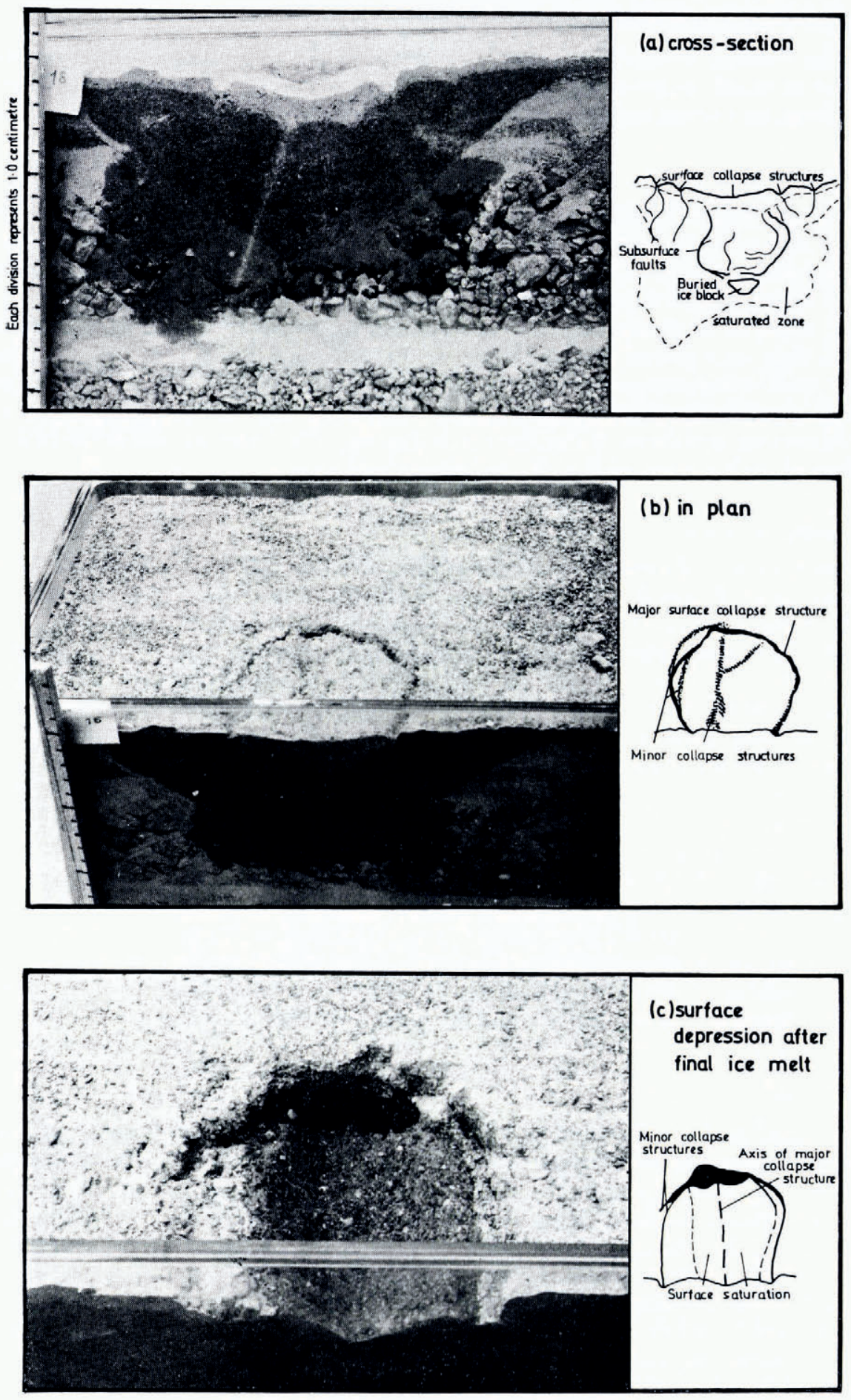

Fig. 9. Collapse structures produced by the melting of a buried ice block. $(a),(b)$ and $(c)$ as labelled. 


\section{Constraints OF THE EXPERIMENTS}

Further testing is required in order to establish the reliability of these experiments as analogues of much larger-scale pro-glacial phenomena. The main differences between the experimental and actual conditions result from contrasts in scale and in environmental factors.

\section{Scale differences}

Important differences in scale arise in relation to the force of melt-water surface tension, since this only affects grains smaller than sand or gravel size. The pingo-like forms observed in the experiments may not, therefore, necessarily be created by the melting of far larger blocks of ice on much coarser deposits. Differences in the dimensions and weight of the ice block may also prove to be significant; the experimental ice blocks remained level with the surface on which they were placed but, on a large scale, heavy ice blocks may well sink downwards into the underlying sediment as a result of their own weight. The nature of the surface sediment, in particular its grain-size composition, its cohesion and its surface slope, may affect the development and shape of any surface depressions that form, as well as the rates of downslope flow of melt waters, sediments and even ice blocks.

\section{Environmental differences}

Differences in sediment and air temperatures cause differential rates of ice melt; the experimental ice blocks melted within $2-3 \mathrm{~h}$, whereas large-scale ice blocks may take years to melt. Different rates of basal melting and sapping, and of burial by surrounding melt-water sediments may cause different surface configurations to result. Contrasts in initial sediment moisture and permeability also modify the rates of basal melting and sediment redistribution; melt water percolates into a dry sediment but remains on the surface of a saturated sediment or flows away as surface run-off, carrying sediment with it. Different melt-water temperatures, sediment and discharge conditions would affect the rates of melting of ice blocks situated in melt-water streams. The rate at which depressions are infilled with sediment or the rate of sediment removal by melt-water streams would also differ according to local melt-water and sediment regimes.

Further experiments might aim to investigate the surface response to buried ice blocks melting in a saturated deposit, and to simultaneous melting of ice blocks in a variety of positions in the sediments. Larger ice blocks and coarser sediments could be used to try to reduce the effects of melt-water surface tension observed in some of the present experiments. The origin and development of other ice-stagnation, pro-glacial or periglacial features might also be tested experimentally along similar lines to those illustrated in this paper.

\section{Conclusions}

The largest and most permanent kettle-holes resulted from the melting of buried blocks of ice. Smaller transient depressions were formed in stream channels, especially where meltwater flow was reduced and ice blocks were free of supra-glacial debris. No central depressions were formed from the melting of blocks of ice on a dry sediment surface but the resultant pattern of fine and coarse sediments directly reflected the original diameter of the ice block. Surface mounds or ridges resulting from the experimental melting of ice blocks on the surface may resemble the landforms which characterize pingos, push moraines or stone-banked lobes and which are found in actual pro-glacial or periglacial environments. Experiments using larger ice blocks and coarser sediments are still required in order to examine further the possibility that some of these forms may also be created by the surface melting of stagnant blocks of ice. 
The experimental results support those workers who have advocated the buried-ice origin of kettle-holes. Little evidence has been forthcoming on the likelihood that any large kettleholes are created by the melting of ice partially buried in melt-water streams. There is no evidence that kettle-holes form from the melting of stagnant ice lying on an outwash surface, where flowing water is absent.

\section{Acknowledgements}

The author would like to thank Dr C. Embleton, Miss A. Coleman and Dr G. Scott of King's College, University of London, for their valuable comments on the original draft of this paper.

\section{MS. received 22 June 1976 and in revised form 28 September 1976}

\section{REFERENCES}

Broscoe, A. J. 1972. Some aspects of the geomorphology of meltwater streams, Steele Glacier terminus. (In Bushnell, V. C., and Ragle, R. H., ed. Icefield Ranges Research Project. Scientific results. Vol. 3. New York, American Geographical Society; Montreal, Arctic Institute of North America, p. 47-51.)

Clark, R. P. K. 1969. Kettle holes. Fournal of Glaciology, Vol. 8, No. 54, p. 485-86.

Cotton, C. A. 1942. Climatic accidents in landscape-making. Christchurch, N.Z., etc., Whitcombe and Tombs Ltd.

Davis, W. M. 1890 . Structure and origin of glacial sand plains. Bulletin of the Geological Society of America, Vol. I, p. $195^{-202 .}$

Embleton, C., and King, C. A. M. 1975. Glacial geomorphology. [Glacial and periglacial geomorphology. Second edition. Vol. I.] London, Edward Arnold.

Fahnestock, R. K. 1963 . Morphology and hydrology of a glacial stream-White River, Mt. Rainier, Washington. U.S. Geological Survey. Professional Paper 422-A.

Flemal, R. C. 1976. Pingos and pingo scars: their characteristics, distribution, and utility in reconstructing former permafrost environments. Quaternary Research, Vol. 6, No. 1, p. 37-53.

Flint, R. F. 1971. Glacial and Quaternary geology. New York, John Wiley and Sons.

Fuller, M. L. 1914. The geology of Long Island, New York. U.S. Geological Survey. Professional Paper 82.

Galon, R. 1973. A synthetic description of deposits and landforms observed on the proglacial area of Skeidarárjökull. Conclusions with regard to the age of the deposits and the way in which deglaciation is proceeding. Geographia Polonica, Vol. 26, p. 139-50.

Geikie, J. 1894 . The great ice age, and its relation to the antiquity of man. Third edition. London, E. Stanford.

Gilbert, G. K. 1904. Glaciers and glaciation. New York, Doubleday, Page and Co.

Hobbs, W. H. 1931. Loess, pebble bands, and boulders from glacial outwash of the Greenland continental glacier. Fournal of Geology, Vol. 39, No. 4, p. $38 \mathrm{r}-85$.

Ives, J. D., and Andrews, J. T. 1963 . Studies in the physical geography of north-central Baffin Island, N.W.T. Geographical Bulletin (Ottawa), No. 19, p. 5-48.

Jewtuchowicz, S. 1971. Współczesna strefa marginalna lodowca Skeidararjökull na Islandii [The present-day marginal zone of Skeidarárjökull, Iceland]. Acta Geographica Lodziensia, 27.

Jewtuchowicz, S. 1973. The present-day marginal zone of Skeidarárjökull. Geographia Polonica, Vol. 26, p. 1 1 5-37.

Klimek, K. 1973. Geomorphological and geological analysis of the proglacial area of the Skeidarárjokull. Extreme eastern and extreme western sections. Geographia Polonica, Vol. 26, p. 89-1 I3.

Lougee, R. J. 1940. Deglaciation of New England. Journal of Geomorphology, Vol. 3, No. 3, p. 189-21 7.

Maizels, J. K. Unpublished. A comparison of present-day and Pleistocene proglacial environments, with particular reference to geomorphology and sedimentology. [Ph.D. thesis, University of London, 1976.]

Michel, J. I969. Divers types de phénomènes périglaciaires et leur répartition dans les alluvions quaternaires de la Seine et de ses affluents. (In Ters, M., ed. Études sur le Quaternaire dans le Monde. VIIIe Congrès INQUA, Paris, 1969. Paris, Centre National de la Recherche Scientifique, Vol. 2, p. 721-28.)

Price, R. J. 1969. Moraines, sandar, kames and eskers near Breidamerkurjökull, Iceland. Institute of British Geographers. Transactions, No. 46, p. $17-43$.

Price, R. J. 1971. The development and destruction of a sandur: Breidamerkurjökull, Iceland. Arctic and Alpine Research, Vol. 3, No. 3, p. 225-37.

Price, R. J. 1973. Glacial and fluvioglacial landforms. Edinburgh, Oliver and Boyd.

Rich, J. L. 1943. Buried stagnant ice as a normal product of a progressively retreating glacier in a hilly region. American Journal of Science, Vol. 241, No. 2, p. 95-100.

Svensson, H. 1964. Traces of pingo-like frost mounds. Lund Studies in Geography, Ser. A, Physical Geography, No. 3o, p. $93^{-106 .}$

Tarr, R. S. 1908. Some phenomena of the glacier margins in the Yakutat Bay region, Alaska. Zeitschrift für Gletscherkunde, Bd. 3, Ht. 2, p. 8I-1 10.

Thwaites, F. T. 1926. The origin and significance of pitted outwash. Journal of Geology, Vol. 34, No. 4, p. 308-19. 